DOI https://doi.org/10.36059/978-966-397-244-2-2-3

\author{
Лenex C. M. \\ кандидат юридичних наук, доцент, \\ доцент кафедри теорії права та прав людини \\ Український католицький університет \\ м. Львів, Україна
}

\title{
ЗОБОВ'ЯЗАННЯ ЗА ДОГОВОРОМ БАНКІВСЬКОГО ВКЛАДУ (ДЕПОЗИТУ): СУЧАСНИЙ СТАН ТА ПЕРСПЕКТИВИ ЗАКОНОДАВЧОГО РЕГУЛЮВАННЯ
}

Актуальність обраного предмету дослідження обумовлена необхідністю вдосконалення законодавчого регулювання договірних механізмів залучення коштів професійними учасниками ринку фінансових послуг. В ході численних судових розглядів спорів у сфері банківської діяльності очевидними стали певні прогалини та недоліки правового регулювання депозитних відносин, як наслідок в судовій практиці немає єдності підходів у тлумаченні застосування деяких законодавчих приписів. Метою даного дослідження $\epsilon$ проаналізувати існуючі проблеми та запропонувати шляхи їх вирішення. Так, звертається увага на те, що доцільно об'єднати в межах конструкції депозитного договору механізми залучення фінансових активів (грошових коштів, банківських металів) як банками, так і кредитними спілками. З'ясовано сутність діяльності по залученню грошових коштів як фінансової послуги. Проаналізовано правовий статус сторін договору банківського вкладу і запропоновано частково змінити допустимі межі розпорядження депозитними коштами неповнолітньою особою як вкладником. Досліджено особливості спадкування права на вклад, порядок оформлення прав в порядку такого правонаступництва. Значний інтерес представляють положення щодо форм цивільно-правової відповідальності банку за порушення депозитних споживчих зобов'язань, зокрема відшкодування моральної шкоди. Запропоновано визначити загальні засади відповідальності професійних надавачів фінансових послуг в спеціальному законодавстві.

Проведений в межах даної статті аналіз та його результати можуть використовуватися у подальших наукових дослідженнях 
Новітні досягнення та вектори розвитку сучасної юриспруденції

проблем договірного регулювання депозитних відносин, а також у правотворчій діяльності для удосконалення національного законодавства у сфері фінансових послуг, зокрема, у контексті рекодифікації цивільного законодавства України.

\section{Вступ}

Засади функціонування договірних механізмів в сфері фінансових послуг в Україні активно змінюються, зумовлені впровадженням інноваційних технологій, поширенням процесів цифровізації. Відновлення рівня довіри клієнтів до фінансових установ є одним зі стратегічних завдань професійних учасників ринку фінансових послуг, від цього залежить стан їхньої ліквідності, це впливає на обсяги залучення грошових коштів в економіку країни.

В судовій практиці останніх років поширеними $є$ спори, що виникли з договірних відносин в банківській сфері, в тому числі щодо укладення, виконання депозитних договорів та застосування цивільно-правової відповідальності банку за порушення таких домовленостей. В правозастосовній практиці та науці виникли дискусії щодо з'ясування сутності депозитної послуги, розширення переліку суб'єктів, уповноважених займатись такою діяльністю, умов застосування правонаступництва у випадку смерті вкладника, форм цивільноправової відповідальності банків за порушення умов повернення депозитів, зокрема, допустимості відшкодування моральної шкоди. В Стратегії розвитку фінансового сектору України до 2025 року в межах фінансової інклюзії як одного зі стратегічних напрямів визначено такі цілі: 1. підвищення доступності та рівня користування фінансовими послугами; 2. посилення захисту прав споживачів фінансових послуг; 3. підвищення рівня фінансової грамотності населення. Одним із аспектів їх реалізації $\epsilon$ забезпечення належного рівня правового регулювання депозитних зобов'язань. В процесі рекодифікації національного законодавства в сфері надання фінансових послуг слід звернути увагу на питання оптимізації договірних механізмів залучення коштів та банківських металів як фінансових активів на засадах ïх повернення. На сьогодні правом надавати депозитні послуги наділені банки за договорами банківського вкладу (депозиту) та кредитні спілки за договорами про залучення внеску (вкладу). В контексті фінансової інклюзії визначення спільних та 
Новітні досягнення та вектори розвитку сучасної юриспруденції

відмінних законодавчих засад залучення фінансових активів банками та кредитними спілками сприятиме усвідомленому вибору споживачем надавача цієї фінансової послуги.

\section{1. Поняття та правова природа договору банківського вкладу}

Відповідно до частини 1 статті 1058 Цивільного кодексу України (далі - ЦК України) за договором банківського вкладу (депозиту) одна сторона (банк), що прийняла від другої сторони (вкладника) або для неї грошову суму (вклад), що надійшла, зобов'язується виплачувати вкладникові таку суму та проценти на неї або дохід в іншій формі на умовах та в порядку, встановлених договором.

Договір банківського вкладу (депозиту) відноситься за чинним законодавством до договорів про надання фбінансових послуг. Відповідно до пункту 5 частини 1 статті 1 Закону України «Про фінансові послуги та державне регулювання ринків фінансових послуг» фінансова послуга - це операції 3 фінансовими активами, що здійснюються в інтересах третіх осіб за власний рахунок чи за рахунок цих осіб, а у випадках, передбачених законодавством, - і за рахунок залучених від інших осіб фінансових активів, 3 метою отримання прибутку або збереження реальної вартості фінансових активів. До фінансових операцій в законодавстві відносять всі операції, пов'язані зі зміною прав власності на фінансові активи, у тому числі виникнення й ліквідація фінансових вимог. Поняття фінансових послуг в законодавстві розкривається через категорію «операції», такий підхід підтримується і в науковій літературі [6, с. 392; 8, с. 570]. Однак, поняттям «операції» часто позначають власне технічні фактичні дії фінансової установи, спрямовані на виконання укладеного договору щодо надання фінансових послуг, вчинення власне банківського правочину або в цілому охоплюють основний договір про надання певної фінансової послуги та супутні договори. Отже, цей термін відтворює публічно-правовий аспект діяльності на ринку фінансових послуг. Для приватно-правового регулювання більш оптимальним $€$ формулювання, запропоноване Денисенком Б. про те, що фінансова послуга полягає у вчиненні фактичних та/або юридичних дій з фінансовими активами [4, с. 58].

Спірною $€$ також у законодавчому визначенні фінансової послуги вказівка на те, що такі дії здійснюються в інтересах 
третіх осіб, під якими в силу відсутності інших законодавчих визначень розуміють самих клієнтів банків та інших фінансових установ $[4$, с. 58]. В цивільно-правовому зобов'язанні треті особи не беруть участі в укладенні договору як підстави його виникнення та набувають за договором лише права. Отже, правовий статус третіх осіб не відповідає обсягу повноважень клієнта/споживача як сторони договору про надання фінансових послуг. Також законодавець у визначенні фінансової послуги вказує, що вона здійснюється в інтересах третіх осіб за власний рахунок чи за рахунок цих осіб, а у випадках, передбачених законом, і за рахунок залучених від інших осіб фінансових активів. У дефініціях цивільно-правових договорів вказівка на те, за чий рахунок надаватиметься послуга означає «хто платить», натомість у наведених випадках мова йде про благо, переміщення якого опосередковуватиме застосування певної договірної форми надання послуг.

Економісти теж звертають увагу на необхідність розмежування таких понять як фінансова послуга, фінансова операція та фінансовий продукт. Так, фінансову послугу пропонують трактувати як сукупність надаваних фінансовою установою професійних видів діяльності на ринку фінансових послуг, безпосередньо не пов'язаних з придбанням матеріальних об'єктів, а спрямовану, в силу договірних зобов'язань, перерозподілити фінансові ресурси між фізичними та/чи юридичними особами. Фінансовою операцією називають особливий системнотехнологічний процес, що поєднує діяльність фінансової установи та споживача, здійснюється від імені першої і спрямований на вирішення визначеної задачі економічного характеру, що формується клієнтом. Фінансові послуги втілюють нематеріальну форму, і їх неможливо реалізувати за конкретно визначеною ціною. Під фінансовим продуктом розуміють сукупність взаємопов'язаних операцій та послуг, систематизованих певним чином 3 наповненням якісно нових якісних ознак та характеристик з метою задоволення окремих споживчих потреб клієнта фінансової установи [1, с. 18-19].

Поряд із поняттям фінансової послуги в законодавстві оперують категорією «фінансовий інструмент», під яким розуміють будь-який контракт, що започатковує виникнення фінансового активу, з одного боку, та фінансового зобов'язання чи інструментів у вигляді акцій - 3 іншого. 
До фінансових належать лише ті послуги, які опосередковують переміщення таких матеріальних благ як фінансові активи, якими $\epsilon$ кошти, цінні папери, боргові зобов'язання та право вимоги боргу, що не віднесені до цінних паперів. Щодо співвідношення понять фінансова та банківська послуга, то очевидним $\epsilon$ те, що частина фінансових послуг надаються небанківськими фінансовими установами, а тому це поняття $є$ родовим, а банківська послуга - видовим.

Дроздова Н.В. виділяє такі характерні ознаки фінансової послуги, що відрізняють її від інших різновидів послуг, а саме: поперше, фінансова послуга - це різновид діяльності відповідного суб’єкта господарювання, який надає послугу; по-друге, фінансова послуга належить до нематеріальних послуг; в-третіх, фінансова послуга супроводжується відповідним рухом фінансових активів (грошових коштів, цінних паперів, боргових зобов'язань та прав вимоги боргу, що не має статусу цінних паперів, включаючи будь-які види лотерейних та інших подібних білетів, які передбачають видачу грошового або майнового виграшу); в-четвертих, зазначений рух фінансових активів передбачає здійснення учасниками таких послуг відповідної фінансової операції (наприклад, торгівля фінансовими активами, залучення їх в депозит); по-п'яте, наявність професійного складу суб'єктів фінансових послуг, які надають таку послугу i здійснюють функцію фінансового посередництва [5, с. 8].

За правовою природою договір банківського вкладу також $\epsilon$ реальним (вважається укладеним з моменту передачі грошей); одностороннім (обов'язки покладені лише на банк, а вкладник має право вимагати повернення вкладу та сплати процентів); оплатним (допускається можливість встановлення доходу для вкладника не лише у вигляді процентів, але й в інших формах; безперечно, що банк отримує певний дохід від діяльності щодо надання депозитних послуг). Договір банківського вкладу, в якому вкладником $\epsilon$ фізична особа, $\epsilon$ публічним договором (частина 2 статті 1058 ЦК України), відповідно до регулювання таких відносин застосовують положення статті 633 ЦК України. Банк не має права відмовитись від його укладення за наявності в нього можливостей надати дану послугу. У разі необгрунтованої відмови банк має відшкодувати клієнтові завдані такою відмовою збитки. Також договір банківського вкладу, в якому вкладником $\epsilon$ фізична особа, $\epsilon$ споживчим договором, до 
регулювання цих відносин застосовують норми Закону України «Про захист прав споживачів».

Відповідно до частини 1 статті 21 Закону України «Про кредитні спілки» кредитна спілка відповідно до свого статуту залучає на договірних умовах внески (вклади) своїх членів на депозитні рахунки як у готівковій, так і в безготівковій формі. Така діяльність опосередковується укладенням договору про залучення внеску (вкладу) на депозитний рахунок (депозитного договору). Очевидно, що така домовленість за своєю правовою природою має багато спільного із договором банківського вкладу. Стаття 1058 ЦК України визначає лише банк в якості сторони, наділеної правом залучення коштів саме за договором банківського вкладу, однак, допустимим є застосування аналогії закону щодо прогалин правового регулювання відносин за договорами про залучення внеску (вкладу), які укладаються кредитними спілками. Укласти такий депозитний договір 3 кредитною спілкою має право іiі член, однак зобов'язання кредитної спілки перед одним своїм членом не можуть бути більше 10 відсотків від загальних зобов’язань кредитної спілки.

Для вирішення питання правового регулювання залучення депозитів кредитними спілками в проекті Закону України «Про кредитні спілки» від 22.02.2021 року № 5125 пропонується відповідно до пункту 15 Розділу XI статтю 1058 ЦК України доповнити новою частиною четвертою такого змісту: «4. Положення цього параграфу, крім частини третьої цієї статті, абзацу другого частини першої статті 1059, частини другої статті 1060, статей 1063-1065 цього Кодексу, застосовуються до відносин, що виникають під час провадження кредитною спілкою діяльності щодо залучення коштів, що підлягають поверненню». Доцільним видається об'єднати засади правового регулювання залучення фінансових активів банками та кредитними спілками в межах єдиної конструкції депозитного договору із врахуванням особливостей ії застосування залежно від специфіки суб’єктного складу відносин.

\section{2. Сторони та треті особи в договорі банківського вкладу. Порядок укладення та форма договору банківського вкладу}

Сторонами договору банківського вкладу є банк та вкладник. Банком $\epsilon$ юридична особа, яка на підставі банківської ліцензії має виключне право надавати банківські послуги (стаття 2 
Закону України «Про банки і банківську діяльність»). Відповідно до статті 47 цього ж нормативного акту банк має право надавати банківські та інші фінансові послуги (крім послуг у сфері страхування), а також здійснювати іншу діяльність, визначену в цій статті. Банк здійснює професійну діяльність на ринках капіталу на підставі ліцензії, що видається Національною комісією з цінних паперів та фондового ринку. Банк має право надавати своїм клієнтам (крім банків) окремі фінансові послуги шляхом укладення 3 юридичними особами (комерційними агентами) агентських договорів.

До банківських послуг належать: 1) залучення у вклади (депозити) коштів та банківських металів від необмеженого кола юридичних і фізичних осіб; 2) відкриття та ведення поточних (розрахункових, кореспондентських) рахунків клієнтів, у тому числі у банківських металах, та рахунків умовного зберігання (ескроу); 3) розміщення залучених у вклади (депозити), у тому числі на поточні рахунки, коштів та банківських металів від свого імені, на власних умовах та на власний ризик.

В той же час, сумнівною видається доцільність надання права займатися цією діяльністю суб'єктам, правовий статус яких на даний час не відповідає вимогам, що встановлені в цілому для надавачів фінансових послуг. Так, проектом Закону України від 20.01.2020 року № 2788 «Про внесення змін до деяких законодавчих актів України щодо фінансових послуг у галузі поштового зв'язку» пропонується 3-поміж іншого внести зміни до статті 1058 ЦК України і назвати відповідну домовленість договором банківського/поштового вкладу (депозиту), надавши можливість виступати його стороною не лише банку, але й національному оператору поштового зв'язку. Надання такому суб'єкту права залучати кошти фізичних та юридичних осіб не має достатньо обгрунтованих економічних засад і стане сферою підвищених фінансових ризиків для його клієнтів.

Вкладник - це юридична або фізична особа, яка здійснила розміщення готівкових (безготівкових) грошових коштів або банківських металів на рахунок у банку чи придбала ощадний (депозитний) сертифікат банку на договірних умовах. Вкладниками можуть бути фізичні, юридичні особи. Щодо юридичних осіб, то розміщувати вільні заощадження на банківських депозитних рахунках вони мають право відповідно до обсягу їхньої правосуб’єктності. 
Відповідно до частини 1 статті 32 ЦК України неповнолітня особа має право самостійно укладати договір банківського вкладу (рахунку) та розпоряджатися вкладом, внесеним нею на своє ім'я (грошовими коштами на рахунку), а частина 3 цієї ж статті ЦК України передбачає право неповнолітньої особи розпоряджатися грошовими коштами, що внесені повністю або частково іншими особами у фінансову установу на її ім'я, за згодою органу опіки та піклування та батьків (усиновлювачів) або піклувальника. Отже, набути прав вкладника неповнолітня особа може у разі укладення договору банківського вкладу безпосередньо нею або на її користь іншою особою. Логічним $\epsilon$ наділення такої особи повноваженням самостійно розпоряджатися вкладом, внесеним нею на своє ім'я. Однак, якщо умовами договору передбачене право поповнення вкладу і надалі кошти вносились не лише самим вкладником, але й іншими особами відповідно до статті 1062 ЦК України, то виникне питання щодо необхідності застосування частини 3 статті 32 ЦК України в контексті розпорядження ними, адже зазначена норма містить загальне правило щодо усіх внесених на ім'я неповнолітнього коштів, незалежно від того, чи відкривається рахунок на ім'я дитини чи кошти вносяться на уже відкритий нею рахунок. Вимога щодо отримання згоди не лише батьків (усиновлювачів, піклувальників), але й органу опіки та піклування значно ускладнює процедуру дострокового розірвання цього договору як в цілому, так і в частині, а також закриття рахунку в разі закінчення строку дії договору. Неврегульованим $\epsilon$ механізм набуття прав вкладника неповнолітньою особою в разі укладення договору банківського вкладу на іiї користь. Відповідно до частини 1 статті 1063 ЦК України третя особа набуває права вкладника 3 моменту пред'явлення нею до банку першої вимоги, що випливає 3 прав вкладника, або вираження нею іншим способом наміру скористатися такими правами. Якщо спосіб вираження наміру набути права вкладника буде одночасно і актом розпорядження вкладом, то для вчинення такої дії неповнолітній особі необхідна згода батьків (усиновлювачів, піклувальників) і органу опіки та піклування.

Отже, в значній кількості випадків реалізація прав вкладника неповнолітньою особою ускладнюється контролем не лише зі сторони батьків (усиновлювачів, піклувальників), але й органу опіки та піклувальника. Враховуючи різноманітні фактори 
Новітні досягнення та вектори розвитку сучасної юриспруденції

функціонування такого механізму (наприклад, відсутність чіткого переліку випадків, коли орган опіки та піклування може відмовити у наданні згоди, невизначеність вимог, які може пред'явити, затягування строків розгляду цього питання), а також очевидну недоцільність застосування такої ускладненої процедури контролю управління майном дитини, яка не позбавлена батьківського піклування, і не $\epsilon$ сиротою, слід визнати, що необхідно концептуально частково змінити правове регулювання депозитних відносин за участю неповнолітнього вкладника. Так, наприклад, Цивільне уложення Німеччини [3] містить різні підходи щодо розпорядження вкладом неповнолітньої особи залежно від того, піклуються про неї батьки чи опікун (якщо дитина позбавлена батьківського піклування чи є сиротою). Так, згідно із §1666 якщо фізичне, психічне або духовне здоров'я дитини або її майно піддається ризику, пов'язаному з неналежним здійсненням батьківської турботи, зневагою до дитини, з поведінкою третьої особи або 3 тим, що батьки не зі своєї вини не справляються 3 їхніми обов'язками, то суд по сімейних справах повинен прийняти необхідні міри щодо усунення цього ризику, оскільки батьки не бажають або не в стані його усунути. Відповідно до §1667 суд по сімейних справах може постановити, що грошові кошти дитини належить вкладати певним чином і для зняття їх 3 рахунків потрібен його дозвіл. Отже, такі заходи вживає суд лише у випадку загрози для благ (зокрема, майна) дитини. Також §1809 передбачено, що опікун зобов'язаний вкладати грошові засоби підопічного 3 вказівкою, що для зняття грошей 3 рахунку потрібен дозвіл контролюючого опікуна або суду по справах опіки. Такі обмеження не застосовуються у випадку звільненої опіки, передбаченої §1852. Доцільним видається запозичити зарубіжний досвід i, зважаючи на особливості договірного регулювання депозитних відносин, оптимізувати умови участі в них неповнолітніх осіб. Зокрема, частину 3 статті 32 ЦК України викласти в такій редакції: «3. Неповнолітня особа може розпоряджатися грошовими коштами, що внесені повністю або частково іншими особами у фінансову установу на іiі ім'я, за згодою батьків (усиновлювачів) або піклувальника. Орган опіки та піклування може прийняти рішення про те, що для зняття грошових коштів з рахунків дитини потрібен його дозвіл». Також статтю 1063 ЦК України доцільно доповнити частиною 3 
наступного змісту: «Неповнолітня особа, на користь якої укладено депозитний договір, має право набувати прав вкладника самостійно, а відмовитись від них має право лише зі згоди батьків (усиновлювачів, піклувальника) та органу опіки та піклування. Договором може бути передбачена умова, що для зняття грошей з рахунку повністю чи в частині до закінчення строку дії договору такою неповнолітньою особою потрібен дозвіл органу опіки та піклування».

Відповідно до частини 1 статті 1228 ЦК України вкладник має право розпорядитися правом на вклад у банку (фінансовій установі) на випадок своєї смерті, склавши заповіт або зробивши відповідне розпорядження банку (фінансовій установі). Отже, спадкування права на вклад може відбуватися за законом, заповітом або заповідальним розпорядженням. Щодо правової природи заповідального розпорядження, то його можна розглядати як різновид заповіту. Фізична особа може зробити відповідне розпорядження банку щодо коштів, що їй належать, на випадок своєї смерті (розпорядження). Якщо розпорядження клієнта складається у формі окремого документа, то на ньому має бути зазначена дата його складання. Цей документ засвідчується підписом уповноваженого працівника банку i зберігається в справі з юридичного оформлення рахунку. Дія розпорядження може бути повністю або частково скасована заповітом, складеним після того, як було зроблене розпорядження банку, якщо в заповіті змінено особу, до якої має перейти право на вклад, або якщо заповіт стосується всього майна спадкодавця.

Одним із питань спадкування права на вклад, яке викликало дискусії та неоднакове застосування судами норм матеріального права, $\epsilon$ питання правонаступництва в депозитних правовідносинах на боці вкладника. Зокрема, виникла дискусія щодо того, чи має право спадкоємець на отримання процентів за договором банківського вкладу, нарахованих лише за життя спадкодавця, чи також і процентів, нарахованих після його смерті до моменту фактичного повернення вкладу. Так, Вищий спеціалізований суд України з розгляду цивільних і кримінальних справ в ухвалі від 27 лютого 2013 року № 6-52730св12 про стягнення недонарахованих відсотків по договорах про заощадження дійшов висновку, що у позивача (дружини) після смерті чоловіка як у спадкоємця виникло право на отримання 
вкладу та процентів на суму вкладу, нарахованих на час смерті спадкодавця. Вимоги щодо стягнення процентів за наступний період після смерті, на думку суду, не грунтуються на законі, відповідач не мав правових підстав для нарахування відсотків по договорах про заощадження після смерті вкладника. Також суд зазначив, що вона не $є$ стороною договорів банківського вкладу, а тому не може вимагати продовження або зміни умов цих договорів після смерті вкладника.

Натомість Верховний Суд України по аналогічних справах висловив правову позицію, зокрема у постанові від 18 вересня 2013 року (справа № 6-65цс13) та в постанові від 22 січня 2014 року (справа № 6-157 цс 13), суть якої зводиться до того, що зобов'язання за договором банківського вкладу не є такими, що нерозривно пов'язані з особою вкладника, а тому в разі його смерті спадкоємцеві, який прийняв спадщину, повертається як сума банківського вкладу, так і проценти на нього до дня, який передує поверненню вкладу. Таку позицію Верховного Суду України слід визнати обгрунтованою, але при цьому слід уточнити, що проценти можуть бути нараховані лише в межах строку чинності депозитного договору.

В порядку спадкування як універсального правонаступництва відбувається перехід прав та обов'язків, що належали спадкодавцеві на момент відкриття спадщини і не припинилися внаслідок його смерті. До складу спадщини не входять права, що нерозривно пов'язані 3 особою спадкодавця, зокрема права вимоги, які призначені для забезпечення засобів для існування саме даній особі - спадкодавцю. Права вкладника не є нерозривно пов'язаними з його особою, а тому входять до складу спадщини. Відповідно до частини 5 статті 1268 ЦК України незалежно від часу прийняття спадщини вона належить спадкоємцеві з часу відкриття спадщини, а отже саме з цього моменту відбувається правонаступництво в депозитному зобов'язанні, до спадкоємця переходять права вкладника.

При цьому слід враховувати і право на частину вкладу другого з подружжя, оскільки такі права вимоги є спільним майном подружжя, якщо вклад внесено під час шлюбу. Так, другий із подружжя може отримати частину такого вкладу як спадкоємець на підставі свідоцтва про право на спадщину, а іншу частину - на підставі свідоцтва про право власності на частку в спільному майні подружжя, яке видається нотаріусом в разі смерті одного 3 
них. Реалізація другим із подружжя права вимоги щодо своєї частини вкладу не опосередковується правонаступництвом, бо право вимоги щодо цієї частини вкладу й так належить цій особі. Оскільки право на вклад не $\epsilon$ нерозривно пов'язаним із особою вкладника, то воно в порядку спадкування як універсального правонаступництва переходить до його спадкоємців в повному обсязі.

Відповідно до статті 1063 ЦК України договір банківського вкладу може бути укладено на користь третьої особи, яка набуває прав вкладника з моменту пред'явлення нею до банку першої вимоги, що випливає з прав вкладника, або вираження нею іншим способом наміру скористатися такими правами. До прикладу, звернутися з вимогою про виплату відсотків, всієї суми чи частини вкладу. До набуття прав особою, на користь якої внесено банківський вклад, ці права належать особі, яка зробила вклад. Керуючись загальною характеристикою договорів на користь третіх осіб, така особа може бути як визначена, так і не визначена в цих домовленостях. Однак, саме в договорі банківського вкладу визначення імені фізичної особи або найменування юридичної особи, на користь якої зроблений вклад, $\epsilon$ істотною умовою. Щодо того, хто саме може бути визначений в якості такої третьої особи, то оскільки ця особа може набути прав вкладника, відповідно слід зробити висновок, що нею може бути визначено лише такого суб'єкта, який може виступати вкладником.

Однією із особливостей досліджуваного договору, в якому вкладником виступає фізична особа, є публічність. Банк не має права відмовитися від укладення договору банківського вкладу з фізичною особою за наявності у нього можливостей надання фінансових послуг. Очевидно, при укладенні договору банківського вкладу на користь третьої особи, якщо вкладником виступає фізична особа, незалежно від того, хто буде третьою особою, теж застосовується правило про публічність. У разі необгрунтованої відмови банку від прийняття вкладу така особа має право звернутися до суду з позовом про відшкодування збитків, завданих такою відмовою. Однак, третя особа такого права мати не може, бо не бере участі в укладенні договору.

3 моменту укладення такого договору третя особа має право набути права вкладника чи відмовитись від них. Це право тісно пов'язане саме із цією конкретною особою, а тому не може бути 
відступлене іншій особі. Право на набуття статусу вкладника має секундарний характер, 3 моменту його реалізації ця особа набуває права вимоги. Для цього особа, на користь якої укладено договір, може звернутися до банку з вимогою про повернення вкладу або його частини, поповнити суму вкладу; вчинити заповідальне розпорядження, в інший спосіб повідомити банк про набуття ним прав. Під час внесення вкладу на користь третьої особи банк ідентифікує особу (у тому числі представника такої особи), яка відкриває рахунок, а особу, на користь якої укладено договір і відкрито рахунок, - під час пред'явлення цією особою до банку першої вимоги або вираження нею іншим способом наміру використати цей рахунок. Однак, слід мати на увазі, що до набуття третьою особою прав вкладника, ці права належать особі, яка зробила вклад, тобто до моменту ідентифікації третьої особи. Спірним видається питання щодо того, чи відбувається з моменту виявлення третьою особою волі щодо вкладу заміна сторони у відповідному зобов'язанні. Відповідно виникає питання щодо статусу особи, яка уклала такий договір в якості вкладника, з моменту набуття цих прав третьою особою. Насамперед, слід звернути увагу на те, що в самому визначенні договору на користь третьої особи (частина 1 статті 636 ЦК України) чітко визначено, що боржник (в даному договорі - банк) зобов'язаний виконати свій обов'язок на користь третьої особи, а не нового кредитора, як це мало б місце в разі заміни первісного. До того ж особа, яка укладає такий договір, має права вкладника до моменту звернення третьої особи, а в разі відмови останньої від цих прав, може вимагати повернення вкладу або переведення його на своє ім'я, тобто знову діяти як кредитор. В європейському законодавстві більш категорично вирішується це питання. Так, відповідно до § 333 Цивільного уложення Німеччини якщо третя особа відмовиться від права, набутого нею на підставі договору стосовно того, хто обіцяв, то це право не вважається набутим. Зважаючи на зазначене, видається більш вдалим закріпити в законодавстві норму, відповідно до якої особа, яка укладає договір банківського вкладу на користь третьої особи, мала б статус сторони в якості кредитора протягом всього періоду існування цього зобов'язання, однак, з моменту набуття третьою особою прав вкладника, особа, яка уклала договір, як кредитор мала б право вимагати виконання банком договірних обов'язків не на свою 
користь, а на користь третьої особи, а в разі відмови останньої від цих прав чи самого прийняття виконання за договором - в свою користь. Таке правило не перешкоджатиме третій особі чи iї правонаступникам самостійно вимагати виконання зобов'язання.

Пропонується наступне визначення досліджуваного договору: «За депозитним договором на користь третьої особи одна сторона (клієнт) зобов'язується передати депозит (грошові кошти, банківські метали), другій стороні (банку, іншій фінансовій організації), яка зобов'язується прийняти і повернути його та сплатити проценти відповідно до умов договору третій особі, за умови набуття нею прав клієнта, або особі, яка уклала договір, за умови ненабуття третьою особою цих прав чи відмови від них».

Щодо укладення договору банківського вкладу застосовується загальний порядок укладення договору з певними особливостями. Документи, які має надати вкладник, передбачені Інструкцією про порядок відкриття і закриття рахунків клієнтів банків та кореспондентських рахунків банків - резидентів і нерезидентів. Договір банківського вкладу може укладатися шляхом приєднання клієнта до публічної пропозиції укладення договору (оферти), яка розміщена у загальнодоступному для клієнта місці в банку та на його офіційному сайті в мережі Інтернет. Банк зобов'язаний надати клієнту в спосіб, визначений банком та клієнтом, у тому числі за допомогою засобів інформаційних, телекомунікаційних, інформаційно-телекомунікаційних систем примірник договору, що дає змогу встановити дату його укладення.

В процесі вирішення спорів, пов'язаних із порядком укладення депозитних договорів, дотриманням їх форми, виникли дискусії щодо тлумачення відповідних норм матеріального права та неоднакове їх застосування судами. За моментом укладення усі цивільно-правові договори класично поділяють на консенсуальні та реальні. Одним із небагатьох реальних правочинів $є$ договір банківського вкладу, таку характеристику правової природи чітко відображено в самому законодавчому визначенні його поняття, адже банк бере на себе певні зобов'язання щодо уже прийнятої від вкладника або іншої особи на його користь грошової суми (вкладу). Однак, визначення моменту укладення договору банківського вкладу обумовлює не лише загальне правило, передбачене частиною 2 статті 640 ЦК України, але й дотримання 
його форми. Вимоги щодо форми договору банківського вкладу визначені статтею 1059 ЦК України, відповідно до якої цей правочин вчиняється у письмовій формі. Письмова форма договору банківського вкладу вважається додержаною, якщо внесення грошової суми підтверджено договором банківського вкладу з видачею ощадної книжки або сертифіката чи іншого документа, що відповідає вимогам, встановленим законом, іншими нормативно-правовими актами у сфері банківської діяльності (банківськими правилами) та звичаями ділового обороту. При цьому квитанція (другий примірник прибуткового касового документа) або інший документ $\epsilon$ підтвердженням про внесення готівки у відповідній платіжній системі.

У разі недодержання письмової форми договір банківського вкладу $\epsilon$ нікчемним. Однак, досить ускладнена процедура дотримання вимог закону щодо такої письмової форми обумовила не лише різне розуміння цих норм, але й створила можливості для масових порушень працівниками банку порядку укладення таких договорів і внаслідок цього привласнення ними коштів, які фізичні особи бажали розмістити на вкладних (депозитних) рахунках в банках. Схеми таких протиправних дій були різні. Найбільш поширеними стали випадки, коли працівники, уповноважені від імені банку залучати фінансові активи від населення, при отриманні від клієнтів грошових сум в якості вкладів, на підтвердження депозитної домовленості видавали лише сам письмовий договір, однак не видавали квитанції чи іншого документа, передбаченого банківськими правилами, оскільки вкладних (депозитних) рахунків на ім'я таких осіб не відкривали і відповідно не розміщували на них кошти, а забирали їх собі. В інших випадках, навіть за умови видачі вкладникам ощадних книжок чи інших документів, що допускаються банківськими правилами, не відкривали рахунки та не обліковували на них відповідні кошти. 3 часом, коли такі ошукані вкладники звертались до банку 3 вимогами про повернення основних сум та процентів за такими домовленостями, в банку їм повідомляли про те, що жодних договорів з банком вони не укладали, кошти на відповідні рахунки не потрапляли. В судовій практиці щодо розгляду та вирішення таких категорій справ виникли розбіжності щодо з'ясування моменту укладення самого договору банківського вкладу, дотримання його форми і відповідно його неукладеності 
чи нікчемності в наведених випадках. Щодо ситуацій, коли від імені банку уповноважені працівники видавали необхідні документи, однак, рахунки не відкривались, Верховний Суд України дійшов висновку, що відкриття банківських рахунків та обліковування на них грошових коштів, залучених від юридичних і фізичних осіб на підставі укладеного в письмовій формі договору банківського вкладу (депозиту), є обов'язком банку. У зв'язку 3 цим відсутність реєстрації договору банківського вкладу i, як наслідок, необліковування грошових коштів, залучених від юридичних і фізичних осіб на підставі укладеного в письмовій формі договору банківського вкладу, не можна вважати недодержанням письмової форми договору банківського вкладу за наявності ощадної книжки (сертифіката) чи іншого документа, що відповідає вимогам, установленим законом, іншими нормативно-правовими актами у сфері банківської діяльності (банківськими правилами) та звичаями ділового обороту, і $\epsilon$ підтвердженням про внесення готівки у відповідній платіжній системі. Відповідні юридичні факти (відсутність банківських рахунків і, як наслідок, необліковування на них грошових коштів, залучених від юридичних і фізичних осіб на підставі укладеного в письмовій формі договору банківського вкладу) слід кваліфікувати як невиконання банком своїх обов'язків за договором банківського вкладу (постанови Верховного Суду України від 25 квітня 2012 року в справі № 6-20цс12, від 6 червня 2012 року в справі № 6-17цс12).

У разі недодержання письмової форми договору банківського вкладу цей договір є нікчемним. Велика Палата Верховного Суду конкретизувала правовий висновок Верховного Суду України, сформульований у постановах від 29 листопада 2017 року у справі № 6-109цс17, від 6 червня 2012 року у справі № 6-17цс12 та від 29 жовтня 2014 року № 6-118цс14, щодо письмової форми правочину банківського вкладу, зазначивши, що суди мають у порядку, передбаченому процесуальним законом, перевіряти доводи сторін і досліджувати докази стосовно додержання письмової форми договорів банківського вкладу, враховуючи, що недотримання уповноваженими працівниками банку вимог законодавства у сфері банківської діяльності та внутрішніх вимог банку щодо залучення останнім вкладу (депозиту) (зокрема, й через видання документів на підтвердження внесення коштів, які не відповідають певним вимогам 
законодавства й умовам договору банківського вкладу) не може свідчити про недотримання сторонами письмової форми цього договору (постанова Великої Палати Верховного Суду від 10 квітня 2019 року в справі № 463/5896/14-ц).

Однак, такі судові спори вказують на те, що в законодавстві чітко не визначено етапи досягнення домовленості між банком та клієнтом щодо залучення депозитів, ускладнено вимоги щодо письмової форми, не конкретизовано момент укладення самого договору. Доцільним видається відмовитись від реального характеру договору банківського вкладу і визначити його як консенсуальний. Натомість розмежувати момент укладення договору (підписання його сторонами в простій письмовій формі) та момент набрання ним чинності (внесення суми вкладу). Така проста письмова форма є достатньою, в законі та самому тексті договору імперативно передбачати умову про момент набрання ним чинності як внесення грошової суми 3 видачею квитанції (однакового документа у всіх фінансових установах). Вдосконалення законодавчого регулювання порядку укладення договору банківського вкладу в цілому має посилити убезпечення участі та створення додаткових гарантій реалізації прав клієнтів.

В ощадній книжці, яка може видаватись банком, вказуються найменування і місцезнаходження банку (його філії), номер рахунка за вкладом, а також усі грошові суми, зараховані на рахунок та списані з рахунка, а також залишок грошових коштів на рахунку на момент пред'явлення ощадної книжки у банк. Відомості про вклад, вказані в ощадній книжці, $є$ підставою для розрахунків за вкладом між банком і вкладником.

Видача банківського вкладу, виплата процентів за ним і виконання розпоряджень вкладника про перерахування грошових коштів 3 рахунка за вкладом іншим особам здійснюються банком у разі пред’явлення ощадної книжки. Якщо ощадну книжку втрачено або приведено у непридатний для пред'явлення стан, банк за заявою вкладника видає йому нову ощадну книжку.

Сума внесеного вкладу та права вкладника також можуть підтверджуватись ощадним сертифікатом. Відповідно до статті 26 Закону України «Про ринки капіталу та організовані товарні ринки» ощадний сертифікат банку - це цінний папір, який підтверджує суму вкладу, внесеного в банк, і права 
вкладника (власника сертифіката) на одержання після спливу встановленого строку суми вкладу та процентів, встановлених сертифікатом, у банку, який його видав. Ощадний сертифікат банку є неемісійним цінним папером, що видається на певний строк (під проценти, передбачені умовами його видачі). Ощадні сертифікати банків можуть бути виключно ордерними та існують виключно у паперовій формі. Особа, зазначена в ощадному сертифікаті банку, може передати право власності на такий сертифікат іншій особі лише шляхом вчинення повного (іменного) індосаменту. Дохід за ощадними сертифікатами банку виплачується під час пред’явлення їх для оплати в банк, що розмістив сертифікати.

\section{3. Зміст договору банківського вкладу. \\ Відповідальність банку за договором банківського вкладу. Гарантування вкладів фізичних осіб}

ЦК України не містить статті, яка б передбачала істотні умови досліджуваного договору, хоч в науковій літературі були пропозиції таких законодавчих змін [7, с. 14]. Однак, при його укладенні слід враховувати положення статті 6 Закону України «Про фінансові послуги та державне регулювання ринків фінансових послуг», а також пункту 8 Інструкції про порядок відкриття і закриття рахунків клієнтів банків та кореспондентських рахунків банків - резидентів і нерезидентів, відповідно до якого у договорі банківського вкладу обов'язково зазначаються: 1) вид банківського вкладу; 2) сума, що вноситься або перераховується на вкладний (депозитний) рахунок; 3) строк зберігання коштів (за строковим вкладом); 4) розмір і порядок сплати процентів або доходу в іншій формі, умови перегляду їх розміру, відповідальність сторін; 6) інші умови за погодженням сторін.

Зважаючи на те, що договір банківського вкладу належить за чинним законодавством до групи договорів про надання послуг, умова про предмет має містити не лише характеристику сутності правового режиму фінансових активів, щодо обігу яких сторони домовляються, але й самої банківської депозитної послуги, тобто дій по залученню фінансових активів із зобов'язанням щодо наступного їх повернення. На сайтах банків розміщують інформацію про істотні характеристики послуги банківського вкладу (депозиту). Відповідно до Закону України 
«Про фінансові послуги та державне регулювання ринків фінансових послуг» до фінансових активів належать кошти, фінансові інструменти, цінні папери, боргові зобов'язання та право вимоги боргу, що не віднесені до цінних паперів. Вклад (denoзum) - це грошові кошти в готівковій або безготівковій формі у валюті України або в іноземній валюті або банківські метали, які банк прийняв від вкладника або які надійшли для вкладника на договірних засадах на визначений строк зберігання чи без зазначення такого строку (під процент або дохід в іншій формі) і підлягають виплаті вкладнику відповідно до законодавства України та умов договору. Відповідно за договором банківського вкладу може передаватися національна чи іноземна валюта, банківські метали, які надходять у власність банку, а у вкладника залишається зобов'язального характеру право вимоги такої ж їх кількості з перебігом встановленого строку чи на першу вимогу. Відповідно дискусійним $€$ сформульований науковий висновок про те, що з моменту внесення грошових сум до банку вкладник втрачає на них право власності як на речі, визначені родовими ознаками, і набуває права власності на вклад як особливий об'єкт права власності [2, с. 6].

Грошові кошти на вкладні (депозитні) рахунки перераховуються юридичними особами 3 поточних рахунків i повертаються банками в безготівковій формі на поточні рахунки юридичних осіб, крім випадків, передбачених законодавством України. Грошові кошти на вкладні (депозитні) рахунки фізичних осіб можуть бути внесені готівкою, перераховані 3 іншого вкладного (депозитного) рахунку або поточного рахунку i повертаються банками готівкою або в безготівковій формі на зазначений у договорі рахунок вкладника для повернення коштів чи за заявою вкладника на інший його рахунок. Як зазначив Верховний Суд у постанові від 20 березня 2019 року по справі № 761/26293/16-ц у разі, якщо договором банківського вкладу передбачено повернення коштів шляхом їх перерахування на поточний рахунок вкладника, із чим погодились обидві сторони, укладаючи такий договір, то після здійснення зазначеної операції правовідносини сторін трансформуються у правовідносини банківського рахунку відповідно до положень частини 3 статті 1058 ЦК України. Така трансформація означає, що вкладник має право отримати готівкою повернуті банком на поточний рахунок кошти за вкладом, але до правовідносин між ними вже не 
можуть застосовуватись положення договору строкового банківського вкладу у зв'язку з тим, що строк його дії закінчився.

На вкладний (депозитний) рахунок зараховуються грошові кошти, які надійшли до банку на ім'я вкладника від іншої особи, якщо договором банківського вкладу не передбачено інше. При цьому вважається, що вкладник погодився на одержання грошових коштів від іншої особи, надавши їй необхідні дані про рахунок за вкладом. На вимогу вкладника до банку про видачу вкладу не поширюється позовна давність (стаття 268 ЦК України).

Відповідно до статті 1060 ЦК України договір банківського вкладу укладається на умовах видачі вкладу на першу вимогу (вклад на вимогу) або на умовах повернення вкладу зі спливом встановленого договором строку (строковий вклад). Договором може бути передбачено внесення грошової суми на інших умовах її повернення. Крім пред’явлення першої вимоги та закінчення строку дії договору банківського вкладу, іншою умовою повернення вкладу може бути настання певного юридичного факту, наприклад, одруження, досягнення вкладником пенсійного віку, повноліття. Види договорів банківського вкладу можуть передбачатися правилами, розробленими банком.

За договором банківського вкладу на вимогу банк зобов'язаний видати вклад або його частину на першу вимогу вкладника. Умова договору банківського вкладу на вимогу про відмову від права на одержання вкладу на першу вимогу $є$ нікчемною.

За договором банківського строкового вкладу банк зобов'язаний видати вклад та нараховані проценти за цим вкладом із спливом строку, визначеного у договорі банківського вкладу. Повернення вкладникові банківського строкового вкладу та нарахованих процентів за цим вкладом на його вимогу до спливу строку або до настання інших обставин, визначених договором, можливе виключно у випадках, якщо це передбачено умовами договору банківського строкового вкладу.

Якщо вкладник не вимагає повернення суми строкового вкладу зі спливом строку, встановленого договором банківського вкладу, або повернення суми вкладу, внесеного на інших умовах повернення, після настання визначених договором обставин договір вважається продовженим на умовах вкладу на вимогу, якщо інше не встановлено договором. 
Відповідно до статті 1061 ЦК України банк виплачує вкладникові проценти на суму вкладу в розмірі, встановленому договором банківського вкладу. Це дохід вкладника, задля якого він замовив банківську депозитну послугу. Їх розмір обчислюється на підставі відсоткової ставки (наприклад, 8\% річних), визначеної договором. Якщо договором не встановлений розмір процентів, банк зобов'язаний виплачувати проценти у розмірі облікової ставки Національного банку України.

У банківській практиці визначається порядок виплати відсотків в договорах, або банківських правилах. Залежно від того, виплачуються відсотки щомісячно (щоквартально) чи повністю в кінці строку договору, диференціюються і відсоткові ставки. Якщо інше не передбачено договором, то проценти виплачуються вкладникові на його вимогу зі спливом кожного кварталу окремо від суми вкладу, а невитребувані у цей строк проценти збільшують суму вкладу, на яку нараховуються проценти. Проценти на вклад нараховуються від дня, наступного за днем надходження до банку грошових коштів або банківських металів, до дня, який передує поверненню грошових коштів або банківських металів вкладнику або списанню 3 вкладного (депозитного) рахунку вкладника з інших підстав.

Серед питань, які викликали певні дискусії та обумовили неоднакову судову практику, є зокрема, період часу, протягом якого можуть бути нараховані проценти в таких депозитних зобов'язаннях. Згідно із частиною 5 статті 1061 ЦК України проценти на банківський вклад нараховуються від дня, наступного за днем надходження вкладу у банк, до дня, який передує його поверненню вкладникові або списанню з рахунка вкладника 3 інших підстав. Зазначене правило в умовах фінансової кризи та масового неповернення банками депозитів викликало різні тлумачення на практиці саме щодо визначення періоду часу, протягом якого можуть нараховуватись такі проценти. Верховний Суд України звернув увагу на неоднакове застосування касаційним судом положень статті 1061 ЦК України, що потягло ухвалення різних за змістом судових рішень у подібних правовідносинах. Так, Вищий спеціалізований суд України з розгляду цивільних і кримінальних справ в ухвалах від 05 жовтня 2011 року, 25 січня 2012 року, 15 лютого 2012 року, 15 серпня 2012 року, 13 лютого 2014 року виходив з того, що після закінчення строку дії договору у відповідача (банку) 
припиняється обов'язок по нарахуванню та виплаті позивачу (вкладнику) процентів по строковому вкладу, незалежно від виконання зобов'язання банком в частині повернення самого вкладу. Однак, цей же касаційний суд в ухвалі від 27 серпня 2014 року дійшов висновку, що проценти мають бути сплачені до дня фактичного повернення грошей, зокрема по даній справі до 08 червня 2011 року, хоча строк дії відповідних договорів банківських вкладів закінчився 20 грудня 2010 року, однак, банк не повернув вчасно вклади. Позицію, висловлену касаційним судом щодо застосування статті 1061 ЦК України в ухвалі від 27 серпня 2014 року Верховний Суд України визнав правильною.

Отже, Верховний Суд України у постанові від 28 січня 2015 року № 6-247цс14 у зв’язку з неоднаковим застосуванням касаційним судом статті 1061 ЦК України сформулював правову позицію, суть якої зводиться до того, що період часу, за який можуть сплачуватися банком вкладникові проценти відповідно до частини 5 статті 1061 ЦК України не обмежується лише строком дії самого договору, а обумовлюється часом фактичного використання банком суми вкладу.

Однак, така правова позиція Верховного Суду України видається спірною, зважаючи на наступне. Відповідно до частини 1 статті 631 ЦК України строком договору є час, протягом якого сторони можуть здійснити свої права і виконати свої обов'язки відповідно до договору. Отже, призначення строку дії договору, зокрема, в тому, щоб встановити межі реалізації прав та виконання обов'язків за договором, відповідно це і визначення тривалості самих прав та обов'язків. За договором банківського вкладу банк бере на себе обов'язок нарахувати проценти за час дії цього договору, а вкладник саме за цей період має право вимагати ix нарахування та виплати. При цьому, у випадку невиконання цього обов'язку банком після закінчення строку дії договору вкладник має надалі право вимагати сплати відсотків, але лише в частині невиконаного договірного обов'язку, тобто сплати процентів, нарахованих протягом строку дії договору. Крім того, слід враховувати правову сутність процентів як доходу вкладника за правомірне використання його фінансового активу протягом обумовленого договором строку. Після закінчення строку дії договору таке використання $\epsilon$ уже неправомірним, до того ж вкладник звертався 3 вимогою про повернення коштів, що підтверджує його незгоду на подальше їх використання банком. 
Отже, стаття 1061 ЦК України визначає порядок нарахування процентів за період правомірного використання фінансового активу, переданого вкладником, і не регулює засад застосування відповідальності за порушення договірних зобов'язань. Після закінчення строку дії договору банківського вкладу обов'язок банку щодо виплати процентів припиняється, залишається лише обов'язок сплати процентів в частині нарахованих за час дії договору, але невиплачених. Натомість подальше використання суми вкладу без згоди вкладника або пролонгації домовленості $\epsilon$ неправомірним, становить порушення умов договору і має наслідком застосування цивільно-правової відповідальності, в тому числі і передбаченої статтею 625 ЦК України.

Банк сплачує вкладнику суму вкладу (депозиту) і нараховані за ним проценти: 1) у національній валюті, якщо грошові кошти надійшли на вкладний (депозитний) рахунок у національній валюті; 2) у валюті вкладу (депозиту), якщо грошові кошти надійшли на вкладний (депозитний) рахунок в іноземній валюті, або на умовах та в порядку, передбачених договором, відповідно до заяви вкладника - в іншій іноземній чи в національній валюті; 3) у банківських металах, якщо вкладний (депозитний) рахунок відкритий у банківських металах, або на умовах та в порядку, передбачених договором, відповідно до заяви вкладника-у національній валюті.

Банки можуть відповідно до умов договору банківського вкладу перераховувати проценти за вкладами (депозитами) на поточний рахунок вкладників, для поповнення вкладу (депозиту) або видавати готівкою вкладникам - фізичним особам.

Закон передбачає право банку на зміну розміру процентів за договором банківського вкладу, укладеного на вимогу, оскільки в результаті інфляційних процесів, зміни грошово-кредитної політики НБУ, зміни співвідношення попиту та пропозиції банк може зазнати збитків внаслідок виплат завищених відсотків. Диспозитивний характер даної норми дозволяє відмовитись від цьогоправа в самому договорі, або обтяжити його реалізацію додатковими умовами.

Встановлений договором розмір процентів на строковий вклад або на вклад, внесений на умовах його повернення у разі настання визначених договором обставин, не може бути односторонньо зменшений банком, якщо інше не встановлено законом. Умова договору щодо права банку в односторонньому 
Новітні досягнення та вектори розвитку сучасної юриспруденції

порядку змінювати розмір процентів на строковий вклад $\epsilon$ нікчемною.

Зважаючи на реальний та односторонній характер договору банківського вкладу, вкладник по суті не має зобов'язань перед банком, а тому й не несе перед ним відповідальності, отже, мова може йти саме про відповідальність банку перед вкладником.

Певний період часу були дуже поширеними судові справи щодо повернення вкладів, розміщених на рахунках Ощадбанку СРСР. Зрештою, різна судова практика обумовила потребу у тлумаченні окремих аспектів цього питання Конституційним Судом України. Суб’єктом права на конституційне подання був Уповноважений Верховної Ради України з прав людини, який звернувся 3 клопотанням щодо відповідності Конституції України положень статей 7, 8 3У «Про державні гарантії відновлення заощаджень громадян України», який вважав, що положення зазначених статей цього Закону порушують конституційні права і свободи громадян України, передбачені, зокрема, статтями $3,13,22,41,48$ Конституції України, а також міжнародні стандарти прав людини. Мається на увазі встановлений Законом порядок, за яким заощадження громадян, відновлені та проіндексовані згідно з цим Законом в установах Ощадного банку України, повертаються поетапно, залежно від віку вкладника, суми вкладу, інших обставин, у межах коштів, передбачених для цього Державним бюджетом України на поточний рік (стаття 7), а у разі смерті вкладника - лише їх частина, сума якої визначається виходячи з розміру державної допомоги на поховання (стаття 8). Конституційний Суд України вирішив: 1. визнати такими, що не відповідають Конституції України ( $\epsilon$ неконституційними), положення статті 7 Закону України «Про державні гарантії відновлення заощаджень громадян України» від 21 листопада 1996 року N 537/96-ВР (із змінами) в частині щодо повернення заощаджень громадян України, іноземних громадян та осіб без громадянства, відновлених та проіндексованих згідно 3 цим Законом в установах Ощадного банку України, залежно «від віку вкладника» та «інших обставин»; визнати таким, що відповідає Конституції України ( $\epsilon$ конституційним), положення статті 8 Закону України «Про державні гарантії відновлення заощаджень громадян України» (Рішення Конституційного Суду України № 13-рп/2001 від 10.10.2001 року у справі за конституційним 
Новітні досягнення та вектори розвитку сучасної юриспруденції

поданням Уповноваженого Верховної Ради України з прав людини щодо відповідності Конституції України (конституційності) положень статей 7, 8 Закону України «Про державні гарантії відновлення заощаджень громадян України», за конституційним зверненням Воробйова В.Ю., Лосєва С.В. та інших громадян щодо офіційного тлумачення положень статей 22,41 , 64 Конституції України (справа про заощадження громадян № 1-23/2001).

Стаття 58 Закону України «Про банки і банківську діяльність» містить норму про те, що банк відповідає за своїми зобов'язаннями всім своїм майном відповідно до законодавства. Глава 71 ЦК України не містить спеціальних норм про відповідальність банку за порушення свої зобов'язань перед вкладником. Підлягає застосуванню відповідальність за порушення грошового зобов'язання, передбачена ст. 625 ЦК України, відповідно до якої боржник, який прострочив виконання грошового зобов'язання, на вимогу кредитора зобов'язаний сплатити суму боргу з урахуванням встановленого індексу інфляції за весь час прострочення, а також три проценти річних від простроченої суми, якщо інший розмір процентів не встановлений договором або законом. При цьому, три проценти річних стягуються у валюті основного зобов'язання, передбаченого договором. Особливістю відповідальності за невиконання чи неналежне виконання грошових зобов'язань $\epsilon$ те, що відсутність у боржника грошей i, як наслідок, неможливість виконання ним грошового зобов'язання, не звільняють боржника від відповідальності за прострочення грошового зобов'язання, оскільки гроші завжди є в обігу. При цьому, у постанові Верховного Суду України від 30 квітня 2014 року у справі № 2218/8430/2012 висловлений правовий висновок, що до правовідносин банківського вкладу в банківському металі положення статті 625 ЦК України не застосовуються.

У постановах від 11 травня 2016 року у справі № 6-37цс16, від 13 березня 2017 року у справі № 6-2128цс16, від 7 грудня 2016 року у справі № 6-362цс16, від 13 вересня 2017 року у справі № 6-1881цс16 Верховний Суд України дійшов висновку, що фізична особа як вкладник за договором депозиту $\epsilon$ споживачем фінансових послуг, а банк їх виконавцем та несе відповідальність за неналежне надання цих послуг, передбачену частиною 5 статті 10 Закону України «Про захист прав споживачів», а саме сплату пені у розмірі 3 \% вартості послуги за 
кожний день прострочення. Суть банківської депозитної послуги полягає в діях по залученню фінансових активів із зобов'язанням щодо наступного їх повернення. В той же час, суд нараховував таку пеню з розміру утримуваної банком суми. 3 цим погодилась і Велика Палата Верховного Суду (постанова від 20 березня 2019 року у справі № 761/26293/16-ц), при цьому за матеріалами даної справи після закінчення строку дії договору банківського вкладу (депозиту) кошти були перераховані на поточний рахунок клієнта, тобто застосовувались положення договору банківського рахунку, але надалі не видавались банком на вимогу клієнта (колишнього вкладника). I в цьому випадку суд теж дійшов висновку, що відмова банку виконати розпорядження клієнта 3 видачі належних йому за договором банківського рахунку сум свідчить про невиконання банком своїх зобов'язань та має наслідком настання відповідальності, передбаченої законом у вигляді сплати пені в розмірі 3 \% від суми утримуваних банком коштів за кожен день 3 моменту звернення клієнта 3 вимогою про видачу коштів до дня фактичної видачі. Виникає питання: чи можна суму банківського вкладу та нараховані проценти як дохід вкладника вважати вартістю депозитної послуги, або суму коштів на поточному рахунку вартістю послуг по банківському обслуговуванню за договором банківського рахунку? Видається, що вартість депозитної послуги чітко не зафіксована, не відображена в договорі банківського вкладу. Фактично банк як фінансовий посередник бере плату з вкладника за депозитну послугу, але не узгоджує її розмір з клієнтом, з економічної точки зору вона становить різницю між тим, що банк зміг заробити на кредитуванні/розміщенні залучених коштів, і тим, що сплатив вкладникові як проценти/дохід. Саме тому нарахування пені, передбаченої частиною 5 статті 10 Закону України «Про захист прав споживачів», від суми утримуваних банком коштів не можна вважати справедливим, зважаючи на економічну сутність депозитних зобов'язань. Щодо порушень прав споживачів в сфері фінансових послуг мають бути встановлені спеціальні законодавчі приписи, в тому числі і щодо стягнення неустойки.

В постанові від 1 вересня 2020 року в справі № 216/3521/16-ц Велика Палата Верховного Суду відступила від відповідного висновку про застосування статей 4 та 22 Закону України «Про захист прав споживачів», викладеного у постанові Великої 
Палати Верховного Суду від 20 березня 2019 року у справі № 761/26293/16-ц в частині застосування норм права при вирішенні питання про відшкодування моральної шкоди за порушення договору банківського вкладу. Вирішуючи спір щодо відшкодування моральної шкоди за порушення споживчого договору, зокрема у справі про порушення банком зобов'язання 3 повернення вкладу, суди мають враховувати, що моральна шкода за порушення цивільно-правового договору як спосіб захисту суб'єктивного цивільного права може бути компенсована і в тому разі, якщо це прямо не передбачено законом або тим чи іншим договором, і підлягає стягненню на підставі статей 16 та 23 ЦК України і статей 4 та 22 Закону України «Про захист прав споживачів» навіть у тих випадках, коли умовами договору право на компенсацію моральної шкоди не передбачено.

Правові, фінансові та організаційні засади функціонування системи гарантування вкладів фізичних осіб встановлені Законом України «Про систему гарантування вкладів фізичних осіб». Установою, що виконує спеціальні функції у сфері гарантування вкладів та виведення неплатоспроможних банків 3 ринку і ліквідації банків $\epsilon$ Фонд гарантування вкладів фізичних осіб. Фонд $\epsilon$ юридичною особою публічного права, має відокремлене майно, яке є об'єктом права державної власності і перебуває у його господарському віданні. Учасниками Фонду $\epsilon$ банки. Участь банків у Фонді $\epsilon$ обов'язковою. Банк набуває статусу учасника Фонду в день отримання ним банківської ліцензії і зобов'язаний сплачувати до Фонду визначені законом збори. Фонд має право безоплатно одержувати від банку інформацію про його діяльність, пояснення з окремих питань, будь-які документи, необхідні для здійснення перевірки та виконання Фондом інших функцій. Банк виключають з числа учасників Фонду в разі прийняття рішення про відкликання банківської ліцензії та ліквідацію банку.

Фонд гарантує кожному вкладнику банку відшкодування коштів за його вкладом. Фонд відшкодовує кошти в розмірі вкладу, включаючи відсотки, станом на день початку процедури виведення Фондом банку з ринку, але не більше суми граничного розміру відшкодування коштів за вкладами, встановленого на цей день, незалежно від кількості вкладів в одному банку.

У разі прийняття Національним банком України рішення про відкликання банківської ліцензії та ліквідацію банку у 
визначених законом випадках Фонд гарантує кожному вкладнику банку відшкодування коштів за вкладами, включаючи відсотки, на день початку процедури ліквідації банку, але не більше суми граничного розміру відшкодування коштів за вкладами, встановленого на дату прийняття такого рішення, незалежно від кількості вкладів в одному банку. Фонд завершує виплату гарантованих сум відшкодування коштів за вкладами у день подання документів для внесення до Єдиного державного реєстру юридичних осіб запису про ліквідацію банку як юридичної особи.

\section{Висновки}

Підсумовуючи усе вищевикладене, можна зробити висновок щодо доцільності внесення концептуальних змін до законодавчого регулювання депозитних зобов'язань із врахуванням наукових напрацювань та судової практики, економічного підгрунтя цих відносин. В процесі рекодифікації цивільного законодавства України необхідно вирішити питання меж уніфікації правового регулювання залучення фінансових активів банками та кредитними спілками. Важливими питаннями в контексті внесення законодавчих змін щодо договірного регулювання відносин в сфері надання депозитних послуг $є$ уточнення суб'єктного складу та деталізації правового статусу сторін та третіх осіб в таких договорах, вдосконалення порядку їх укладення, виконання та розірвання, виокремлення форм цивільно-правової відповідальності фінансової установи за невиконання чи неналежне виконання зобов'язань щодо повернення депозитів.

\section{Література:}

1. Бачо Р.Й. Ринки небанківських фінансових послуг: регулювання розвитку (інституційні та аналітичні аспекти): монографія. Ужгород: Вид-во «РІК-У», 2016. 448 с.

2. Біда М.А. Договір банківського вкладу (депозиту) за цивільним законодавством України: автореф. дис. ... канд. юрид. наук. Київ, 2011. 20 с.

3. Гражданское уложение Германии : ввод. закон к Гражд. уложению; пер. с нем. / [В. Бергманн, введ., сост.]; науч. редакторы А.Л. Маковский [и др.]. 2-е изд., доп. М.: Волтерс Клувер, 2006. 816 с. 
4. Денисенко Б. Банківська послуга як цивільно-правова категорія. Вісник Київського університету імені Тараса Шевченка. Юридичні науки. Вип. 79. С. 55-59.

5. Дроздова Н.В. Договір про надання фінансових послуг у цивільному праві України: автореферат дис. ... канд. юрид. наук. Київ, 2005. 26 с.

6. Солошкіна І.В. Фінансові послуги як правова категорія: поняття, суттєві сторони та інші ознаки. Форум права. 2013. № 4. С. 388-394.

7. Спіжов В.В. Договір банківського вкладу (депозиту) за цивільним законодавством України: автореф. дис... канд. юрид. Харків, 2009. 23 с.

8. Ящищак О.Р. Зміст поняття фінансових послуг у законодавстві України. Правова держава. Випуск 18. К.: Ін-т держави і права ім. В.М. Корецького НАН України, 2007. С. $565-571$. 